\title{
Effectiveness of Biological and Leaf Insecticides to Control the Chilli (Capsicum annum) Pest in Ternate Island
}

\author{
Betty Kadir Lahati ${ }^{1, *}$, Sugeng Haryanto ${ }^{1}$ \\ ${ }^{I}$ Department of Agrotecnology, Faculty of Agriculture, University of Khairun, Ternate, North Maluku, Indonesia \\ *Corresponding author.Email:bettylahati@gmail.com
}

\begin{abstract}
The aim of this research is to learn the effectiveness of biological and leaf insecticides against the population and attack intensity of pests on chilli crops. Factorial Randomized Block Design (RBD) was used in this experiment, while there are two factors,i.e. biological insecticide(isolate of Beauveriabassiana) and leaf insecticide (extract of Annonamuricata). The first factor (B. bassiana) consist of $100 \mathrm{~g} / \mathrm{l}$ of water (H1), 150 $\mathrm{g} / \mathrm{l}$ of water (H2), $200 \mathrm{~g} / \mathrm{l}$ of water (H3), whilst the second factor (extract of Annonamuricata) consist of 100 $\mathrm{g} / \mathrm{l}$ of water (N1), $150 \mathrm{~g} / \mathrm{l}$ of water (N2), $200 \mathrm{~g} / \mathrm{l}$ of water (N3). Application was conducted on 15, 30,45, 60, 75, and 90 days after planting. The result showed that the higher concentration of both B.bassiana and Annonamuricata were used, the lower population and attack intensity of pests in chilli crops. However, no significant effect of the combination of treatments.
\end{abstract}

Keywords: biocontrol agents, leaf insecticide, Beauveriabassiana, Annonamuricata

\section{INTRODUCTION}

Chili is one type of vegetable which is also used as a spice that has a high economic value, because it contains antioxidants that function to protect the body from free radical attack and also acts as an anti-cancer agent. So far, the production of the City of Ternate in particular, has been unable to meet the needs of the community. the need for cabbage reaches 1.5 tons per 3 days but often experiences vacancies by always importing cabed from outside Ternate City such as from North Sulawesi, Manado. Cabedi cultivation in Ternate has experienced many pests and diseases, resulting in reduced production of cabemen. Some alternative pest control by using Beauveria bassiana and soursop leaves which is an environmentally friendly pest control that is part of IPM. These two methods of control are very rare because farmers generally still rely on chemical insecticides. The use of synthetic insecticides in excessive doses has been a barrier to the realization of sustainable agriculture [7].

Beauveria bassiana is an insect pathogenic fungus (entomophatogen) which is now used to control insect pests. Beauveria bassiana has a broad spectrum of control and can control many species of pests from agricultural crops [1]. Reports that B. bassiana fungus can infect and cause death to Apis sp. and Bemesia tabaci on plants as well as several types of insects from the order of coleopteran, lepidotera and orthoptera [6]. In Indonesia, $B$. bassiana mushrooms have been tested on various types of agricultural crop pests but have not given tangible results [5] The effectiveness of B. bassiana as a controller of a number of insect pests has been proven through various studies [8].

Soursop plant (Annona muricata). This plant is known to have anti-cancer, anti-bacterial, cytotoxic activity, and has a high antioxidant content [9]. Soursop leaf Annona muricata, where soursop leaves, including plant-based insecticides are often used also to control several pests including grasshopper pests, Thrips sp larvae. in chili plants, because the sisrsak leaves contain contact poisons containing phytosterols, tannins, Ca-oxalates and alkaloids which are very useful to be used as a vegetable insecticide. Besides being able to control these plant-based insecticides, including environmentally friendly insecticides. Based on these thoughts, it is necessary to test the effectiveness of biological and vegetable insecticides in controlling pests on chilli plants, especially in the city of Ternate. The purpose of this study was to examine the effectiveness of both biological and vegetable insecticides on the mortality of chili pests and attacks / damage caused by chili pests

\section{METHODS}

This research will be carried out in August - December 2015. The place of the implementation of phase 1 in the agrotechnology laboratory of the Faculty of Agriculture, 
Khairun University, Ternate for the manufacture of biological insecticides and vegetable insecticides. The second step is to plant chilli farmers to test the effectiveness of both insecticides.

The tools and materials to be used are chilli plants, raffia ropes, traps, soursop extract (Annona muricata) treatment boards, Beauveria bassiana isolates, handsprayers, cardboard glue, markers, millimeter blocks, jars, gauze, rubber bands, insect determination books.

The method used was an experimental method with factorial randomized group design. Factor H(biological): Factor H (biological): $\mathbf{H 1}=$ dose of $100 \mathrm{~g}$ / liter of water; $\mathbf{H 2}=150 \mathrm{~g} /$ liter water dose; $\mathbf{H 3}=$ dose of $200 \mathrm{~g} /$ liter of water. Factor N (Vegetable): N1 = dose of $100 \mathrm{~g} /$ liter of water; $\mathbf{N 2}=$ dose of $150 \mathrm{~g} /$ liter of water; $\mathbf{N 3}=200 \mathrm{~g} /$ liter dose of water. Treatment Combinations: H1N1; H1N2; H1N3:H2N1; H2N2; H2N3: H3N1; H3N2; H3N3 with applied every day after the plant ie $15 \mathrm{hst}$, 30hst.45hst, $60 \mathrm{hst}, 75 \mathrm{hst}$, 90hst.

Research Implementation; Manufacture of biological insecticides (B. Bassiana) as follows: $\neg$ Before the implementation of making solid media all the tools are sterilized in autoklav for 2 hours after that, wash the rice thoroughly and drain, steamed in a container for 15 minutes, remove and cool for 15-20 minutes, after a cold pack into a heat-resistant plastic bag, sterilize in the cage for 2 hours, cooled again for 15 -20 minutes, planting entomophatogen isolate B. Bassiana, using a simple encase, incubation for 14 days with observations every day, successful isolates will be used as biological agents that are ready to be applied in the field.

Manufacture of Vegetable / Botanical Insects (Annona muricata) as follows:

Soursop leaf collection that will be used as an extract, finely mash 100 soursop leaves, Soak in 5 liters of water, add $15 \mathrm{gr}$ of detergent until blended and let stand overnight, filter the lartan with a soft cloth, Dilute according to the treatment needed, Ready for application. Application

Spraying is done when planting 15 days after planting, 30 days after planting, days after planting, after planting, after planting 15 days after planting, and after planting. The application is done in the morning or evening. Each spray is used as a test in each treatment. Infected larvae on the ground will be taken by placing a trap in the observation area

Observation Parameters; Observations made in the study of the use of entomopathogenic fungi are:

- Observation of chilli pest mortality is done periodically / weekly observation

- When observing, it is necessary to collect and identify the types of infected insect pests from the control results in the treatment plot

- Monitor the number of plants attacked in the treatment plot
- Monitor the number of plants that are not attacked in the treatment plot.

\section{Data analysis}

To calculate the percentage of attacks is as follows [13] $\mathrm{PS} \%=\mathrm{Nh} / \mathrm{Nt}$ X $100 \%$

Where:

$\mathrm{PS}=$ percentage of attacks

$\mathrm{Nh}=$ the number of plants attacked in each observation $\mathrm{Nt}=$ the total number of plants in each observation to assess the intensity of damage/attack on intruder organisms in chilli plants using the absolute formula as follows:

$\mathrm{IS}=\left(\Sigma_{-}((\mathrm{n} \times \mathrm{v}))\right) /(\mathrm{Z} \times \mathrm{N}) \times 100 \%$

Where: IS = attack / damage intensity (\%)

$\mathrm{n}=$ number of damaged leaves per attack category

$\mathrm{v}=$ scale value of each attack category

$\mathrm{Z}=$ highest scale value of attack category

$\mathrm{N}=$ number of leaves observed

Table 1. Crop damage scale

\begin{tabular}{|c|c|l|}
\hline $\begin{array}{c}\text { Scale } \\
\text { Value }\end{array}$ & $\begin{array}{c}\text { High Damage to } \\
\text { Plants (\%) }\end{array}$ & \multicolumn{1}{|c|}{ Category } \\
\hline 0 & $0 \%$ & Not attacked \\
\hline 1 & $\leq 25 \%$ & Very mild intensity \\
\hline 2 & $>25-50 \%$ & Mild intensity \\
\hline 3 & $<50-75 \%$ & Medium intensity \\
\hline 4 & $>75 \%$ & Heavy intensity \\
\hline
\end{tabular}

To analyze the combination of the two treatments using a real difference test analysis

\section{RESULTS AND DISCUSSION}

\section{The Effectiveness of the Biological and Vegetable Insecticide on the Insect Population Of Pest Attacks}

\section{Percentage of pest insect population in chili fields treated with B. bassiana biological insecticide}

Based on observations and identification of the types of pepper pests in the Laboratory of the Faculty of Agriculture, University of Khairun on the percentage of pest insect populations in the chilli land on an area of $4.2 \mathrm{~m}$ $\mathrm{x} 4.2 \mathrm{~m}$ with a spacing of $50 \mathrm{~cm} \times 60 \mathrm{~cm}$. Where by using insect traps and net nets, pests found in the species of chili include: Thrips sp, Bemesia tabaci, Apis sp, Spodotera litura, Valanga nigricornis, Locusta migratoria. In the 
observation of chilli insect population population has decreased in the treatment of $\mathrm{H} 3$ with a dose of Beauveria bassiana biological insecticide $200 \mathrm{~g} /$ liter of water at each age of the plant. This can be seen in graph 1 below:

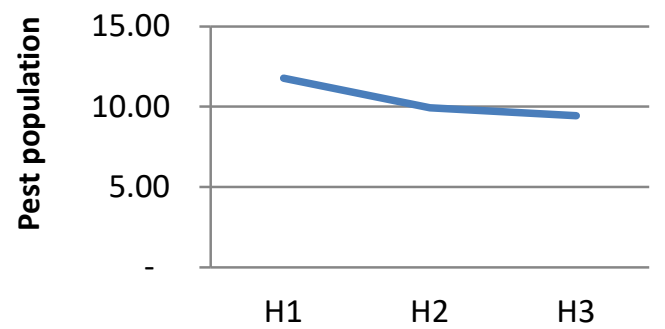

$\mathbf{H}=$ Biological insecticide dose B.bassiana

Figure 1. Percentage of biological insecticide treatment on mortality of chilli pest population.

Population declines are found in a number of pests on the chili plants namely Trips sp., Apis sp, Valanga nigrocornis. Bemesia tabaci (white lice) where the $\mathrm{B}$. basssiana biological insecticide infects the body of the insect begins with host contact through the skin, digestive tract, spiracles and other holes. The fungus inoculum attached to the body of the host insect will germinate and develop to form a germination tube, then enter through the body's skin. Penetration is done mechanically by releasing beauvericin toxin which makes damage to insect body tissue [2]. The symptoms of pathogenic infections in infected insects are insects that appear weak, inactive with reduced immune system. Infected pests turn brown and turn black and their bodies look stiff, overall damage to the body tissues of insects due to a toxin produced by the fungus beauveria $\mathrm{sp}$ namely beauvericin Insect pests infected with this fungus are also seen wrapped by hyphae threads or fungus mycelia that cover the surface of the insect pests. The use of biological insecticides with $\mathrm{Bb}$

Percentage of pest population in the Chilean fields treated with soursop leaf-based insecticide (Annona muricata).

Based on observations of chilli pest population with soursop leaf extract treatment at various doses of concentration where if the concentration of acetogenin is applied low then this compound becomes contact poison and can kill insect pests, but at higher concentrations will cause insects to refuse to eat [4]. This decrease in chilli pest population is caused by soursop leaves in addition to being a contact poison as well as a repellent (refellent) and appetite inhibitor (antifeedant). Other advantages of using this pesticide include being an environmentally friendly pesticide, low cost and can be made by farmers. But in the combination of the two treatments of biological insecticides and plant-based insecticides on pest populations where the Fhit is not real $0.19 \%$. This can be seen in graph 2 below:

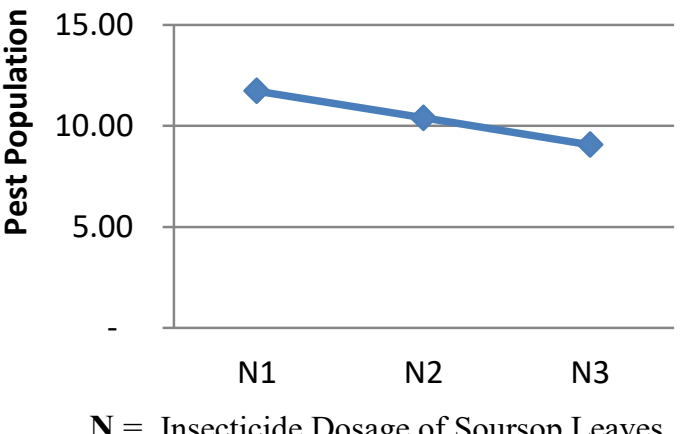

Figure 2. Percentage of plant-based insecticide treatment on mortality of chilli pest populations

This decrease in chilli pest population is caused by soursop leaves in addition to being a contact poison and also as a repellent (refellent) and appetite inhibitor (antifeedant). Other advantages of using this pesticide include being an environmentally friendly pesticide, low cost and can be made by farmers. Soursop leaf extract is effective as a vegetable insecticide. Flavonoids are one of the compounds contained in soursop leaf extracts that function as respiratory inhibitors so as to reduce the rate of chemical reactions that result in impaired respiratory system.

The administration of soursop leaf extract shows the behavior of pest insects become weak and wrinkled. The presence of acetogenin compounds found in soursop leaf extracts can inhibit the formation of ATP in the process of respiration so that the formation of energy is inhibited and then the body volume will shrink with the body from insects affected by spraying soursop leaves will shrink and die.

The combination of biological and vegetable insecticide treatment is related to the pest population in the chilli field

Based on the results of a combination analysis of the influence of biological insecticides and plant-based insecticides in which a single factor has a Fcount 31.25 and a single Factor $\mathrm{N}$ has a Fcount 36.81 , it looks very real then proceed with a Real Difference Test (BNT), after being analyzed with ANOVA it was found that the combination of Factor- Factors Factors $\mathrm{H}$ and $\mathrm{N}$ have no significant effect 0.19 Therefore, treatment must be used individually 


\section{Percentage of Biological and Vegetable Insecticide on Attack / Plant Damage}

\section{Percentage of biological insecticides to damage caused by pest attacks on chili fields}

Based on observations of the effectiveness test of biological insecticides using B. bassiana on the intensity of attack / damage to chilli plants where in each replication in treatment where there is a decrease in the intensity of attack / damage to plants. This can be seen in graph 3 below:

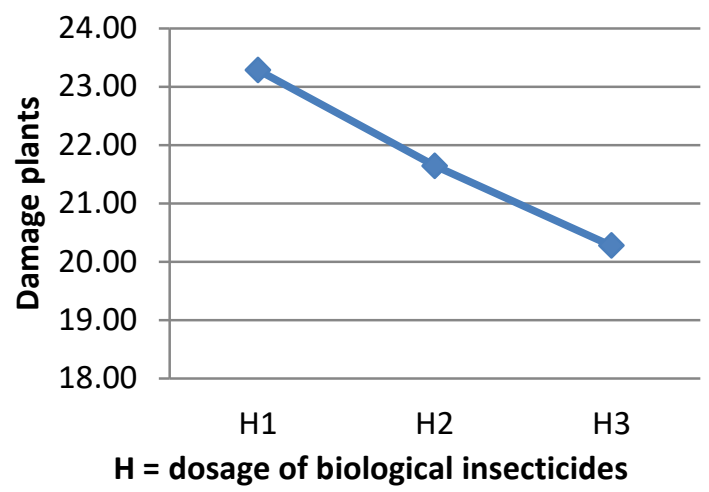

Figure 3. Percentage of biological insecticide treatment against damage to chilli plants

Based on the graph above, it can be seen that the treatment with these biological pesticides repeatedly at each age of the plant there is a decrease in the intensity of attack / damage to the chili plants. This is also caused by the effect of giving a dose where the higher the dose, the pest insects will not eat / do not damage the chilli plants because of the toxic content of beauvericin. Giving this insecticide is better done repeatedly as in this study where at.

States fungus that attaches to the insect's skin will immediately penetrate [11]. Hyphae the fungus that enters secretes the enzyme Chitinase, lipase and proteinase are able outlines the components of the cuticle insects, and also produce toxins that are cause clumping so cessation of blood circulation and damage the digestive tract, the breathing that can cause insect death. Insect deaths caused by the use of entomopathogenic fungi and botanical insecticides in this study directly cause a decrease the percentage of pest attacks on the field every week.

Beauveria bassiana is naturally present in the soil as saprophytic fungi. Fungal growth in the soil is greatly influenced by soil conditions, such as organic matter content, temperature, humidity, eating habits of insects, the presence of synthetic pesticides, and application time. In general, temperatures above $30{ }^{0} \mathrm{C}$, reduced soil moisture and the presence of antifungal or pesticides can inhibit their growth [2].

\section{Percentage of plant-based insecticides on damage caused by pest infestation in chili fields}

This also happened to the intensity of attack / damage to chilli plants in the treatment with soursop leaf vegetable insecticide where there was a decrease in the intensity of attack / damage by chilli pests, as can be seen in graph 4 below:

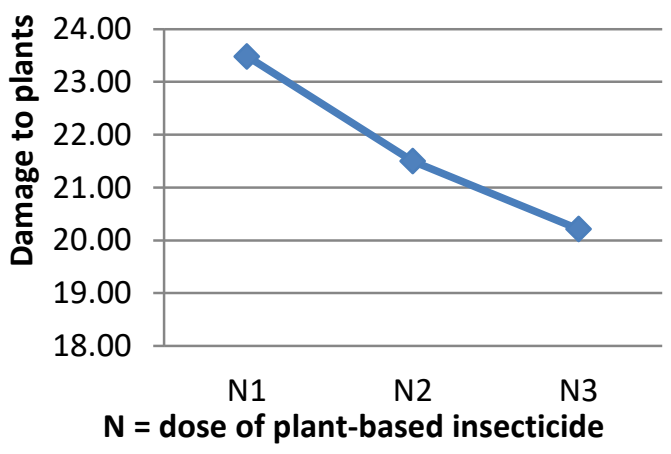

Figure 4. Percentage of plant-based insecticide treatment against attack / damage to chilli plants.

Based on the results of the analysis in the chilli field where the mortality rate at $\mathrm{H} 3$ with $200 \mathrm{~g} /$ ltr of water results in decreased damage to the chilli plants. So it can be concluded that the higher the dosage and the more it is used repeatedly at each age of the chilli plants, the better the soursop extract.

Soursop leaf is a biopesticide derived from plants that contain toxins that can control the insect pests that attack chili plants. Biopesticides are pesticides derived from natural materials such as animals, plants, bacteria and minerals. Biochemical pesticides are chemical compounds extracted from natural sources that can be used in controlling pests. One of the types of biopesticides is plant-based pesticides [12]. Vegetable pesticides are relatively harmless to non-target organisms, including humans and are also biodegradable and do not pollute the environment. Some plants can be used as plant-based pesticides [10]

The combination of biological and vegetable insecticide treatment is related to the pest population in the Chile field

Based on the results of a combination analysis of the influence of biological insecticides and plant-based insecticides in which a single factor has a Fcount 11.79 
and a single Factor $\mathrm{N}$ has a Fcount 14.08 , it looks very real then proceed with a Real Difference Test (BNT), after being analyzed with ANOVA it was found that the combination of Factor- Factors Factors $\mathrm{H}$ and $\mathrm{N}$ have no significant effect 0.08 Therefore, treatment must be used individually

\section{CONCLUSION}

The use of biological insecticides using entomopathatogen Beauveria bassiana is very effective in reducing pest populations and reducing the intensity of damage to chilli plants. Similarly, for plant-based insecticides by using soursop leaf extract (Annona muricata). However, if the two treatments are combined it will not affect the decline in population and the intensity of damage to the chilli plants.

It is hoped that this information can be useful for chilli farmers in ternate cities in particular and North Maluku Province in general. As well as government and stecholder

\section{ACKNOWLEDGMENT}

Thank you to LPPM Unkhair for funding this research and the head of the ternate farmer group and its members

\section{REFERENCES}

[1] Anonim, 2013. Beauveria bassiana. Wikipedia http : //en eikipe-dia./wiki/beauveria_bassiana.

[2] Anonimous, 2011. Insektisida Biologi Beauveriabassiana (diakses di http://www.gerbangpertanian.com/2011/06/insek tisida-biologi-beauveria-bassiana.html).

[3] Fetrina, 2010. Perbanyakan cendawan Beauveriabassiana (Balsoma) Vuillemin pada beberapa jenis limbah organic dan patogenitasnya terhadap Spodopteralitura fabricus (Lepidoptera; Noctuidae), Universitas Andalas Padang.

[4] Ladja, Fausiah T. 2010. Pengaruh aplikasi cendawan B.bassiana dan Verticilliumlecanii terhadap mortalitas Nephotettixvirecens sebagai vector virus tungro. Prosiding seminar ilmiah perhimpunan entomologi Indonesia, Sulawesi Selatan.
[5] Sembel, D.T. Rimbing dan DS Kandowangko.1992. "Pengaruh penggunaan beberapa jenis patogen terhadap tingkat serangan hama bubuk buah kopi, Hypotenemus hampei ferr (Coleoptera scolytidae) pada tanaman kopi dikabupaten Minahasa'J Res \& Dev II (8):62-66

[6] Mars susan1997. The enthomo phatogen Beauveria bassiana. Midwesr Biological control News on line Volume IV Number 10 ,Oktober 1997.

http://www.entomologgy.wisc.edu/mbcn/mbcn4 10.html

[7] Hong-xing, X.U., Ya-jun, Y.,Yan-hui, L.U.,Xusongg,Z.,Jun-ce,T ., Feng-xiang, L Qiang, F.U \& Zhong-xian, L. (2017) Sustainable Management of Rice Insect Pest bby Non-Chemicalinsecticide technologies in china. Rice Science.

[8] Sheeba G,S Seshardi, N Raja,S janarthanan, and S Ignacinutha.2001. Efficacy of Beauveria bassiana for control of the rice weevil Sitophilus oryzae (L) (Coleoptera:Curculionidae). Applied Entomology and zoology 36, 117-120.

[9] Pai, B. H., Rajesh.,G., Shenoy,R., \& Rao, A 2016. Anti microbial Efficacy of Soursop Leaf Extract (Annona muricata) on oral Pathogens://doi.org/10.7860/JCDR/2016/18329. 8762.

[10] Khater, H. F.\& Khater, D . 2009.Tropical medicine rounds the insecticidal activity of four medicinal plants against the blowfly Lucilia sericata (Diptera;calliphoridae) Trop. Med.Rouns,48; 492-497

[11] Mahr. S.,2003. The Enthomophatogen Beauveria bassiana. University of Wincosin, Madison. Diakses dari http://www . entomology, wisc $\mathrm{Edu} / \mathrm{mbcn} / \mathrm{kyF} 410 . \mathrm{html}$. tanggal 14 Maret 2012

[12] Sharma, K. R. \& thakur, S. 2018. Biopesticides: an effective tool for insect pest managent and Indian Journal of Agriculture. Indian J. Agric Allied Sci, 4 : 59-62

[13] Herdiana N. 2010.Potensi serangan hama tanaman jati rakyat dan upaya pengendaliannya di rumpin. Bogor. Jurnal Penelitian Hutan Tanaman (Internet) Tersedia pada http;//fordamof.org/files/7.4.2010_potensiserang an.pdf. 